 \\ z Filologii Polskiej \\ i Słowiańskiej
}

\section{Strefy dialektalne języka białoruskiego jako przykład językowych kontaktów z sąsiednimi narodami}

\section{Wprowadzenie}

W tradycyjnej dialektologii wydziela się dwa pasy dialektów języka białoruskiego - północno-wschodni oraz południowo-zachodni. Centralną część Białorusi obejmują z kolei gwary środkowobiałoruskie. Północno-wschodni dialekt nawiązuje historycznie do mowy plemienia Krywiczów smoleńsko-połockich i pod względem wielu cech łączy się z gwarami rosyjskimi (pskowskimi narzecza północnorosyjskiego oraz kursko-orłowskimi narzecza południoworosyjskiego). Z kolei na obszarze zamieszkałym niegdyś przez Dregowiczów funkcjonuje obecny dialekt południowo-zachodni, wykazujący szereg cech wspólnych z gwarami ukraińskimi ${ }^{1}$. Gwary środkowobiałoruskie nie stanowiły niegdyś odrębnego dialektu i powstały jako efekt kontaminacji

${ }^{1}$ Granice dawnych plemion na ziemiach białoruskich (Krywiczów i Dregowiczów) nie pokrywają się idealnie z zasięgiem współczesnych dialektów.

This is an Open Access article distributed under the terms of the Creative Commons Attribution 3.0 PL License (creativecommons.org/licenses/by/3.0/pl/), which permits redistribution, commercial and non-commercial, provided that the article is properly cited. () The Author(s) 2016. 
dwóch mas dialektalnych (więcej: Крывіцкі, 2003, ss. 129-214; Barszczewska \& Jankowiak, 2012, ss. 35, 132-141). Jak zwraca uwagę Władysław Kuraszkiewicz, geograficzny układ pokazuje, że białoruszczyzna była naturalnym łącznikiem dialektów rosyjskich z ukraińskimi (Kuraszkiewicz, 1963, s. 76), co w swoich pracach pokazywali także George Shevelov i Paul Wexler. Podział taki, oparty na cechach strukturalno-terytorialnych, wynika w dużej mierze z procesów etnogenetycznych, wskazujących na kształtowanie się języka białoruskiego i narodu białoruskiego.

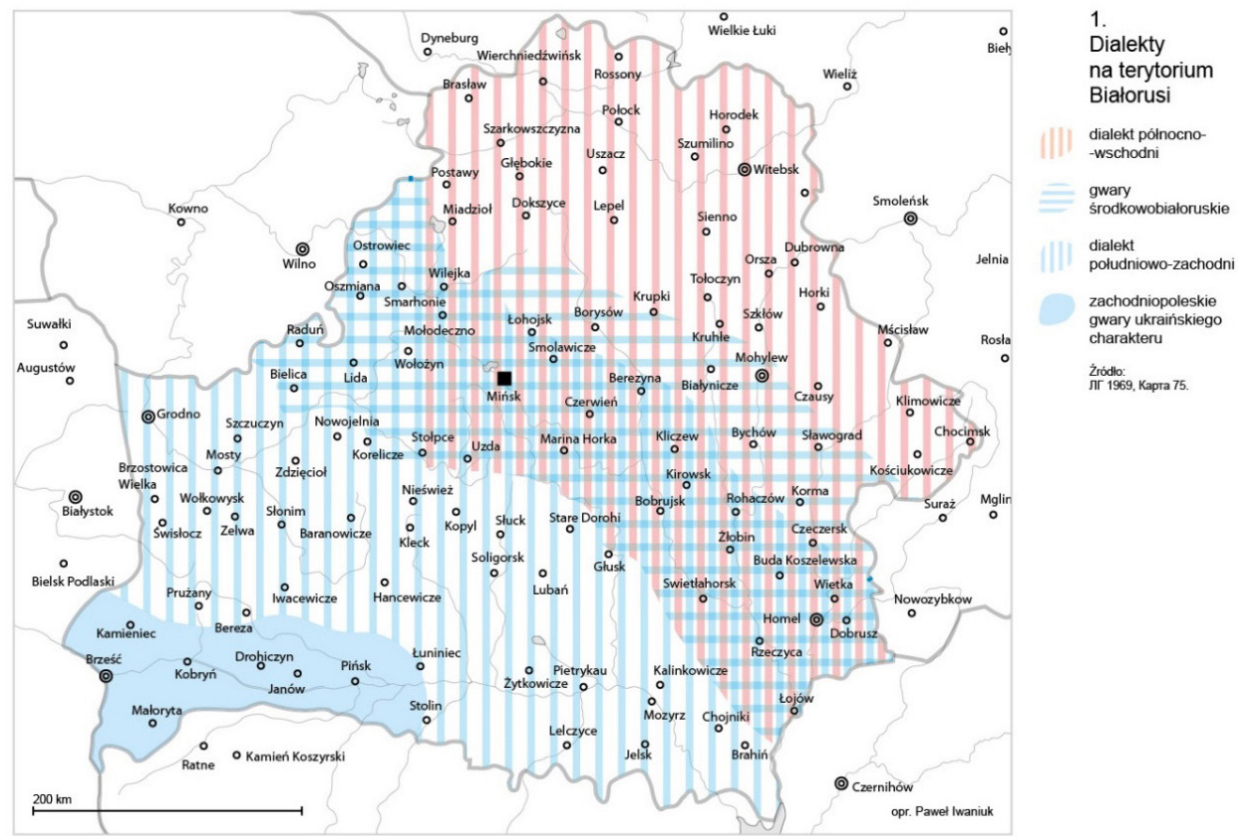

Mapa 1. Dialekty na terytorium Białorusi (Źródło: Barszczewska \& Jankowiak, 2012, s. 229)

Wydanie Dialektologicznego Atlasu Języka Białoruskiego (ДАБМ, 1963) umożliwiło nowe spojrzenie na białoruską dialektologię. Przedstawienie na mapach zasięgu izoglos (w szczególności izoleks, w mniejszym stopniu izofon i izomorf) ukazało dodatkowy w stosunku do tradycyjnego podział gwar białoruskich - tzw. strefy dialektalne języka białoruskiego (biał. дыıялектныя зону беларускай мовы). Nie pokrywają się one ani geograficznie, ani strukturalnie z tradycyjnymi dialektami i grupami gwar, a przecinają je i uzupełniają. Jednocześnie ścisłe określenie granicy zasięgu stref dialektalnych 
wobec pasów dialektów i grup dialektów nastręcza trudności. Wybrane izoglosy nie pokrywają się geograficznie ze sobą i tworzą zgrupowanie pewnych cech na danym terytorium, charakteryzujących zazwyczaj tylko pewną część struktury gwary, zazwyczaj leksykalną (Крывіцкі, 2003, s. 215; Barszczewska \& Jankowiak, 2012, ss. 125, 126).

Od lat 60. XX wieku można zatem mówić o dwupłaszczyznowym analizowaniu podziału gwar w dialektologii białoruskiej. Strefy dialektalne ukazują zazwyczaj innowacyjne procesy, powstałe już po sformowaniu się dialektów tradycyjnych, a odzwierciedlające różnego typu kulturowo-językowe kontakty Białorusinów z narodami sąsiednimi - Litwinami (w mniejszym stopniu z Łotyszami), Rosjanami, Ukraińcami i Polakami. Leksyka stanowi najbardziej otwartą na interferencję część struktury języka, co uwidacznia się bardzo wyraźnie właśnie w strefach dialektalnych. Najczęstszym rezultatem kontaktu dwóch czy większej liczby języków są właśnie zapożyczenia - przede wszystkim leksykalne (Thomason, 2001, s. 11).

W dialektologii białoruskiej wydziela się pięć stref dialektalnych: północno-zachodnią, południowo-wschodnią, zachodnią, wschodnią i centralną. Strefa północno-zachodnia wykazuje związki z mowami bałtyckimi (przede wszystkim z językiem litewskim, mniej z łotewskim, a także z polszczyzną północnokresową), strefa południowo-zachodnia - na związki z północną Ukrainą (Czernihowszczyzna) i rosyjską Briańszczyzną, strefa zachodnia z językiem polskim, a wschodnia - z językiem rosyjskim. Strefa centralna należy do najmniej wyraźnych i łatwych do scharakteryzowania, choć niewątpliwie zrozumienie jej specyfiki jest niezmiernie ważne z punktu widzenia formowania się białoruskiego języka literackiego (Barszczewska \& Jankowiak, 2012, ss. $125-131)$.

Zamierzeniem autora jest zaprezentowanie nieznanego szerzej w polskiej i nie tylko w polskiej dialektologii, innego sposobu podziału gwar i dialektów, ukazującego nie wewnętrzny podział mowy (tj. jedność w ramach jednego języka), lecz zewnętrzny, czyli wynikający ze społeczno-historyczno-kulturowych kontaktów z narodami sąsiednimi. Podział na strefy dialektalne, choć znany białoruskim dialektologom od kilkudziesięciu lat, nie został do dzisiaj dokładnie zbadany i przeanalizowany z punktu widzenia kształtowania się tychże stref $i$ ich genezy ${ }^{2}$.

${ }^{2} \mathrm{~W}$ dialektologii rosyjskiej również istnieje podział na strefy dialektalne. Zostały one wydzielone na podstawie pewnych areałów wybranych cech dialektalnych. Rosyjscy lingwiści 


\section{Stan badań}

Dialektolodzy zarówno polscy, jak i rosyjscy czy ukraińscy nie zwracali szerzej uwagi na kwestię stref dialektalnych w odniesieniu do polszczyzny, języka rosyjskiego czy ukraińskiego ${ }^{3}$. $Z$ białoruskich dialektologów jako pierwszy podniósł tę kwestię Krywicki, a jego idea była podtrzymywana przez Awaniesowa. Badania stref dialektalnych posuwały się jednak na zasadzie małych kroków i wielu znanych dialektologów, jak Hienadź Cychun ${ }^{4}$, nie uznaje stref dialektalnych.

Po raz pierwszy charakterystyka stref dialektalnych została dokonana przez Rubena Awaniesowa, Kandrata Atrachowicza (Kandrata Krapiwę) i Juzefę Mackiewicz w książce i atlasie Lingwistyczna geografia i ugrupowanie gwar białoruskich (ЛГ, 1968, 1969). Jak już wspomniano powyżej, było to możliwe dzięki wydaniu ДАБМ. Autorzy podali w zarysie genezę ich pochodzenia oraz szczegółową analizę cech językowych poszczególnych stref. Przez kolejnych kilkadziesiąt lat zagadnieniem tym nikt się szerzej nie zajmował. W dużej mierze wynikało to $\mathrm{z}$ celów naukowych stawianych w ówczesnych czasach przed dialektologami w ZSRR, tj. prowadzenia badań językowych w administracyjnych granicach swojej republiki ${ }^{5}$. Pewien wyjątek stanowi monumentalna praca dialektologów z kilku krajów (Polski, Białoruskiej SRR, Litewskiej SRR i Łotewskiej SRR), którzy w trakcie eksploracji terenowych zebrali ogromny materiał na pograniczu białorusko-polsko-litewsko-łotewskim. Efektem jest pięciotomowy Słownik gwar białoruskich pótnocno-zachodniej Białorusi i jej pogranicza (СПЗБ, 1979-1986). Obszar gromadzenia materiału w dużej mierze pokrywa się z zasięgiem występowania północno-zachodniej strefy dialektalnej.

nie wskazują jednak na ich związek z narodami sąsiednimi (zob. Захарова \& Орлова, 1970, ss. 82, 83).

${ }^{3}$ Wynika to zapewne z dwóch faktów: wyniki badań dialektologów nie wykazały podobnego fenomenu w odniesieniu do dialektów polskich i rosyjskich, a w przypadku dialektologii rosyjskiej dodatkowo materiał leksykalny może być niewystarczający, aby ukazać takie zjawisko.

${ }^{4}$ Hienadź Cychun nie przyjmuje teorii dotyczącej istnienia stref dialektalnych języka białoruskiego, uznając, że jest to kwestia występowania areałów, a nie stref.

5 Tendencja ta jest widoczna do dzisiaj. Białoruscy dialektolodzy nie często badają np. gwary białoruskie funkcjonujące poza administracyjnymi granicami Białorusi. Nierzadko też, z powodów nienaukowych, granicę administracyjną traktuje się jako zasięg występowania gwary należącej do jednego czy innego języka (np. pogranicze rosyjsko-białoruskie, zob. Касаткин, 2005, s. 265). 
Autorzy większości podręczników dialektologii białoruskiej nie poruszali jednak kwestii stref dialektalnych, charakteryzując tylko tradycyjnie wyznaczone pasy dialektalne i grupy gwarowe (zob. Блінава \& Мяцельская, 1980; Гуліцкая, Гуліцкі, Злобін, \& Рудакоўская, 1992). Jedynie Krywicki w swojej książce zamieścił szerszy opis (Крывіцкі, 2003, ss. 215-230). Już sam ten fakt pokazuje, na ile złożonym zagadnieniem (naukowo i pozanaukowo) są strefy dialektalne.

Obecnie tematyką stref dialektalnych zajmuje się badaczka z Mińska Wiera Astrejka, która opublikowała szereg artykułów na ten temat (Астрэйка, 2006a, 2006b, 2009). Skupia się w nich jednak nie na genezie ich formowania się i fenomenie, a przede wszystkim na opisaniu wybranych cech dialektalnych, wyekscerpowanych $\mathrm{z}$ atlasów dialektologicznych i słowników, ukazujących głównie wpływy bałtyckie czy polskie w gwarach białoruskich (Астрэйка, 1998, 2008, 2010a, 2010b, 2012). Należy również podkreślić, że materiał uwzględniany przez autorkę artykułów oraz autorów podręczników dialektologii białoruskiej ukazuje niestety stan gwar białoruskich sprzed kilkudziesięciu lat. Pewne nadzieje na ujrzenie współczesnego stanu stref dialektalnych niosą najnowsze badania terenowe prowadzone przez licznych badaczy.

Na szczególną uwagę zasługuje najnowsza chrestomatia wydana w 2009 roku pod redakcją Kuncewicz i Kurcowej (Кунцэвіч \& Курцова, 2009). Redaktorki zamieściły w niej teksty gwarowe zapisane przez dialektologów ${ }^{6}$ na obszarze strefy centralnej, głównie obwodu mińskiego, a także mohylewskiego i grodzieńskiego. Przy podjęciu decyzji co do wyboru materiału kierowano się tym, że właśnie gwary centralne odegrały decydującą rolę w kształtowaniu się białoruskiego języka literackiego, a najnowsze teksty z przełomu XX i XXI wieku ukazują szereg ważnych tendencji.

W ostatnim czasie na północno-zachodniej Białorusi były i są prowadzone intensywne badania terenowe ${ }^{7}$. Bardzo dokładnie została zbadana i opisana pod względem leksyki Brasławszczyzna (E. Smułkowa, I. Budźko, O. Guszczewa, H. Kazancewa, I. Kurjan i in.), efektem czego jest dwutomowa praca obejmująca słownik (Smułkowa, 2009) oraz zbiór artykułów (Smułkowa, 2011a), które

${ }^{6}$ W pracach nad chrestomatią wzięli udział: W. Astrejka, N. Buńko, M. Isaczankawa, U. Koszczanka, A. Krywicki, L. Kuncewicz, W. Kurcowa, W. Krupko, A. Ksiandzowa, J. Malicki, T. Truchan, N. Siwickaja, A. Szablouski.

7 Poniżej przytaczam tylko te badania i prace, które bezpośrednio i pośrednio (obszarowo, tematycznie, metodologicznie) łączą się z północno-zachodnią strefą dialektalną. 
traktują o uwarunkowaniach społeczno-historycznych oraz o sytuacji językowej i socjolingwistycznej na tym obszarze (m.in. Smułkowa, 2011b; Budźko, 2011; Kuryan, 2011; Birgiel, 2011; Pabis, 2011; Guszczewa, 2011). Drugi słownik brasławski został z kolei wydany przez J. Riegera (Rieger, 2014). Dialektologiczne eksploracje terenowe były również prowadzone m.in. w Postawskiem (I. Budźko, O. Guszczewa, I. Kapylou, H. Kazancewa, W. Kurcowa, W. Lauczuk), w rejonie Oszmiańskim (O. Guszczewa, H. Kazancewa, W. Lauczuk) czy na Komarowszczyźnie (A. Żebrowska). Poza granicami Białorusi szczegółowo została zbadana Wileńszczyzna (A. Adamkowicz, L. Plyhauka, M. Jankowiak) oraz łotewska Łatgalia (M. Jankowiak) ${ }^{8}$.

Kwestia pograniczy językowych stała się obiektem badań międzynarodowej grupy pracującej w ramach projektu: Pogranicza Białorusi: historia, kultura, język, kierowanego przez prof. Elżbietę Smułkową przy współudziale prof. Anny Engelking 9 . Wybrane pogranicza w dużej mierze pokrywały się ze strefami dialektalnymi: pogranicze polsko-białoruskie (Grodzieńszczyzna i Podlasie 2002 i 2005 rok) - zachodnia i częściowo północno-zachodnia strefa dialektalna; pogranicze białorusko-rosyjsko-ukraińskie (Mozyrszczyzna, 2003 rok) - południowo-wschodnia strefa dialektalna oraz pogranicze białorusko-rosyjskie (Mohylewszczyzna, 2004 rok) - wschodnia strefa dialektalna. Zebrany ogromny materiał dialektologiczny (około 350 kaset) prezentuje również leksykę, charakteryzującą z jednej strony słownictwo typowe dla poszczególnych stref, $\mathrm{z}$ drugiej postępujące $\mathrm{w}$ ostatnich czasach zmiany. Jest to proces rusyfikacji, prowadzący do zaburzenia struktury gwary, przede wszystkim leksyki, także na poziomie idiolektu, co pokazuje zebrany materiał i artykuły zamieszczone w monografii Pogranicza Białorusi w perspektywie interdyscyplinarnej (Smułkowa \& Engelking, 2007; Будзько, 2007, ss. 264-280; Jankowiak, 2007, ss. 302-312).

Geograficznie ze strefą północno-zachodnią pokrywają się również badania prof. B. Wiemera i jego zespołu, realizującego na uniwersytecie w Moguncji projekt Triangulation Approach for Modelling Convergence with a High Zoom-In

8 Zob. Jankowiak (2009) oraz będące w opracowaniu monografie M. Jankowiak, Wspótczesne gwary białoruskie na Łotwie. Wybór tekstów z omówieniem oraz M. Jankowiak, Gwary białoruskie na Litwie. Stan współczesny i fenomen żywotności.

9 Był to kilkuletni projekt (2001-2006) zrealizowany w ramach Międzynarodowej Szkoły Humanistycznej przy Ośrodku Badań nad Tradycją Antyczną w Polsce i Europie Środkowo-Wschodniej Uniwersytetu Warszawskiego (obecnie Wydział „Artes Liberales”). 
Factor, efektem czego jest m.in. książka Aksany Erker dotycząca białoruskich gwar mieszanych na obszarze Brasławszczyzny i okolic Lidy (Эркер, 2015) oraz tworzony elektroniczny korpus gwar pogranicza słowiańsko-bałtyckiego ${ }^{10}$.

\section{Północno-zachodnia strefa dialektalna}

Północno-zachodnia strefa dialektalna należy niewątpliwie do najbardziej archaicznych ze wszystkich pięciu i zarazem najbardziej zróżnicowanych pod względem cech językowych. Sformowała się jako efekt etniczno-językowych procesów słowiańsko-bałtyckich, odbywających się w przeciągu ostatniego tysiąca lat. W odróżnieniu od strefy wschodniej i zachodniej, kontakt odbywał się przede wszystkim na poziomie dialektalnym i w różnych okresach kształtowania się strefy objął takie języki jak: gwary białoruskie, język polski (zwłaszcza polszczyzna północnokresowa), gwary litewskie, gwary łotewskie (łatgalskie) oraz język rosyjski (mowa staroobrzędowców). Strefa ta charakteryzuje się przede wszystkim cechami leksykalnymi, w mniejszym stopniu leksykalno-semantycznymi i słowotwórczymi, a cech fonetycznych jest niewiele (Barszczewska \& Jankowiak, 2012, s. 128).

Tak bogata różnorodność językowa wynika z uwarunkowań historyczno-społecznych - systematycznej slawizacji Bałtów zamieszkujących niegdyś te ziemie, mocnych wpływów polszczyzny północnokresowej (w szczególności w wieku XIX i XX, a w okresie międzywojennym także standardowego języka polskiego ${ }^{11}$ ) oraz wpływów rosyjskich od momentu osiedlenia się staroobrzędowców na terenach północno-zachodniej Białorusi ${ }^{12}$. Poszczególne historyczne etapy kształtowania się strefy bardzo wyraźnie odzwierciedlają się w słownictwie: bałtyzmy stanowią najdawniejsze zapożyczenia, a polonizmy i rusycyzmy są o wiele młodsze. W odróżnieniu od strefy południowowschodniej na północnym zachodzie kontakt $\mathrm{z}$ językami bałtyckimi ma miejsce ciągle, a slawizacja Bałtów następowała o wiele później niż na Homelszczyźnie (Астрэйка, 2010a, s. 183).

${ }_{10}$ Pod redakcją prof. B. Wiemera jest opracowywana monografia pt. Triangulation in the Baltic-Slavic Contact Zone.

11 Większa część obszaru strefy północno-zachodniej w okresie międzywojennym znajdowała się w granicach II RP, gdzie językiem administracji i edukacji był właśnie polski.

12 Zob. na przykład artykuł Pabis (2011). 
Swoim zasięgiem strefa obejmuje północno-zachodnią Białoruś, a jej południową granicę wyznaczają następujące miejscowości: Brasław - na wschód od Szarkowszczyzny - na wschód od Dokszyc - Smolewicze - Czerwień - Uzda Stołpce - Korelicze - na północ od Szczuczyna. Niektóre cechy sięgają znacznie dalej na wschód i południe, po linię: Połock - Uszacz - Lepel - Krupki Bobrujsk - Głusk - Soligorsk - Iwacewicze (ЛГ, 1969, Карта 77).

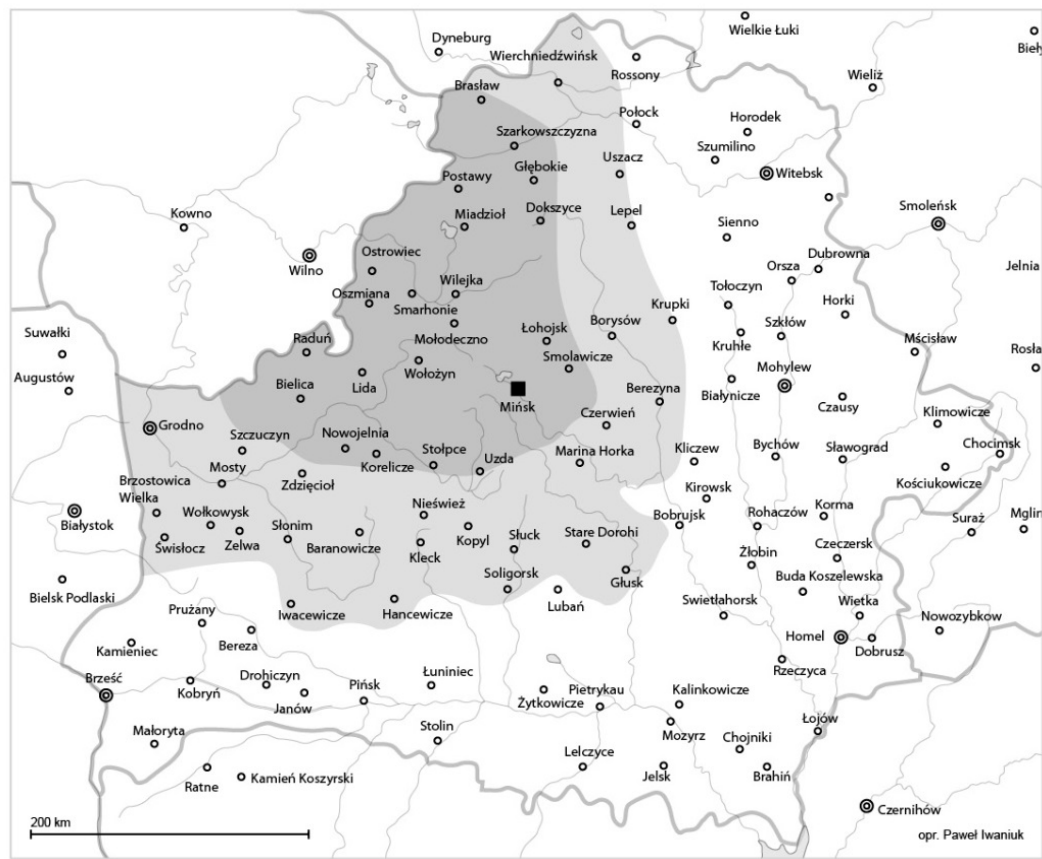

2. Strefa gwar północno-zachodnich Żródb:
תr 1969, Kapra 77.

Mapa 2. Zasięg występowania cech typowych dla strefy północno-zachodniej (Źródło: Barszczewska \& Jankowiak, 2012, s. 232)

Językowe kontakty gwar białoruskich z innymi mowami, przede wszystkim litewską, polską i rosyjską, są najwyraźniej widoczne w słownictwie. Leksyka pochodzenia bałtyckiego ma zazwyczaj charakter archaiczny i związana jest głównie z tradycyjną uprawą roli, codziennym bytem mieszkańców i cechami wyglądu i charakteru człowieka. Za lituanizmy można uznać następujące leksemy: aksna 'osa', knippi 'pazury', kumpiak 'szynka', millta 'potrawa z mąki owsianej', nauda 'korzyść', rojst(a) 'bagnisty teren', szaszok 'tchórz: zwierzę', ziaukać 'otwierać usta; ziewać; mówić byle co' i wiele innych (Астрэйка, 1998, ss. 51-53, 2010b, ss. 11-17). Liczne bałtyzmy, co naturalne, występują również 
w gwarach białoruskich na terytorium Litwy stanowiącym przedłużenie północno-zachodniej strefy (badania własne autora).

Z polonizmów białoruscy dialektolodzy wymieniają m.in. babachaty 'brzuchaty', bonk 'bąk', gałenzia 'gałąź, kauka 'kawka: ptak', pajenczyna 'pajęczyna', pastyr 'pasterz', pszczoła 'pszczoła', skauronak 'skowronek', żabryna 'żebro' i inne. Badacze wyliczyli co najmniej 124 leksemy (w zakresie flory i fauny) typowe dla strefy północno-zachodniej, z czego zapożyczenia stanowią aż 80,6\% (Астрэйка, 1998, ss. 52, 53).

Niektóre cechy językowe (w tym leksykalne) mają charakter lokalny, inne bardziej ogólny. Ze wszystkich leksemów niewątpliwie najdokładniej obszar występowania strefy północno-zachodniej ukazuje zaimek henny 'ten' (ЛГ, 1969, Карта 59; ДАБМ, 1963, Карта 186) oraz postać rzeczownika fasol' 'fasola' (ДАБМ, 1963, Карта 44). Z gramatycznych cech typowych dla tego obszaru można wyliczyć m.in.

- tzw. pełne jakanie: u liesia, u chacia 'w lesie, w chacie';

- powszechność protetycznego (h): hawieccki 'owieczki', hostry 'ostry', hosień 'jesień';

- częste występowanie wybuchowego (g) w wyrazach zapożyczonych: gazêta 'gazeta', garnak 'garnek', gryka 'kasza gryczana';

- mieszanie spółgłosek (k) i (x) pod wpływem języka litewskiego: kliep 'chleb', kusta 'chusta';

- akcentowanie samogłosek wygłosowych w niektórych rzeczownikach r.ż.: skura 'skóra', lipa 'lipa', husia 'gęs', much a 'mucha';

- powszechne występowanie końcówki -au / -ôu w Dop. lm. rzeczowników nie tylko r.m., lecz także r.ż. i r.n.: damou 'domów', drewwau 'drzew', knihhau 'książek';

- powszechne występowanie imiesłowów na -( $w) s z y$ w funkcji predykatywnej, typu: jon byu pajęchauszy u Brasłau 'on pojechał do Brasławia' (Крывіцкі, 2003, ss. 218-221; ЛГ, 1968, ss. 198, 199).

\section{Południowo-wschodnia strefa dialektalna}

Strefa południowo-wschodnia również należy do archaicznych, ale nie jest już tak charakterystyczna i jednorodna pod względem cech dialektalnych jak północno-zachodnia. Część obszaru była zamieszkiwana niegdyś przez Dregowiczów i częściowo Radymiczów, a następnie ziemie te wchodziły w skład księstwa 
czernihowsko-siewierskiego. Nie jest zatem wykluczone, że pewne cechy typowe dla tej strefy powstały jako ówczesne innowacje jeszcze przed sformowaniem się dialektów białoruskich (Астрэйка, 2009, ss. 23, 24). Niektóre z nich uważane były przez białoruskich dialektologów za reliktowe w mowie mieszkańców już kilkadziesiąt lat temu.

Geograficznie strefa południowo-wschodnia obejmuje część dialektu południowo-zachodniego, północno-wschodniego i gwar środkowobiałoruskich, a jej cechy są typowe również dla gwar ukraińskich (północna Czernihowszczyzna) i rosyjskich (zachodnia Briańszczyzna). Zasięg najbardziej wyraźnych cech wyznacza na północy linia: Dubrowna - Orsza - Kruhłe - Marina Horka Kopyl - na zachód od Stolina, a niektóre z nich sięgają nawet po linię: Sienno Krupki - Stołpce - Iwacewicze - Bereza - Kamieniec (ЛГ, 1969, Карта 76).

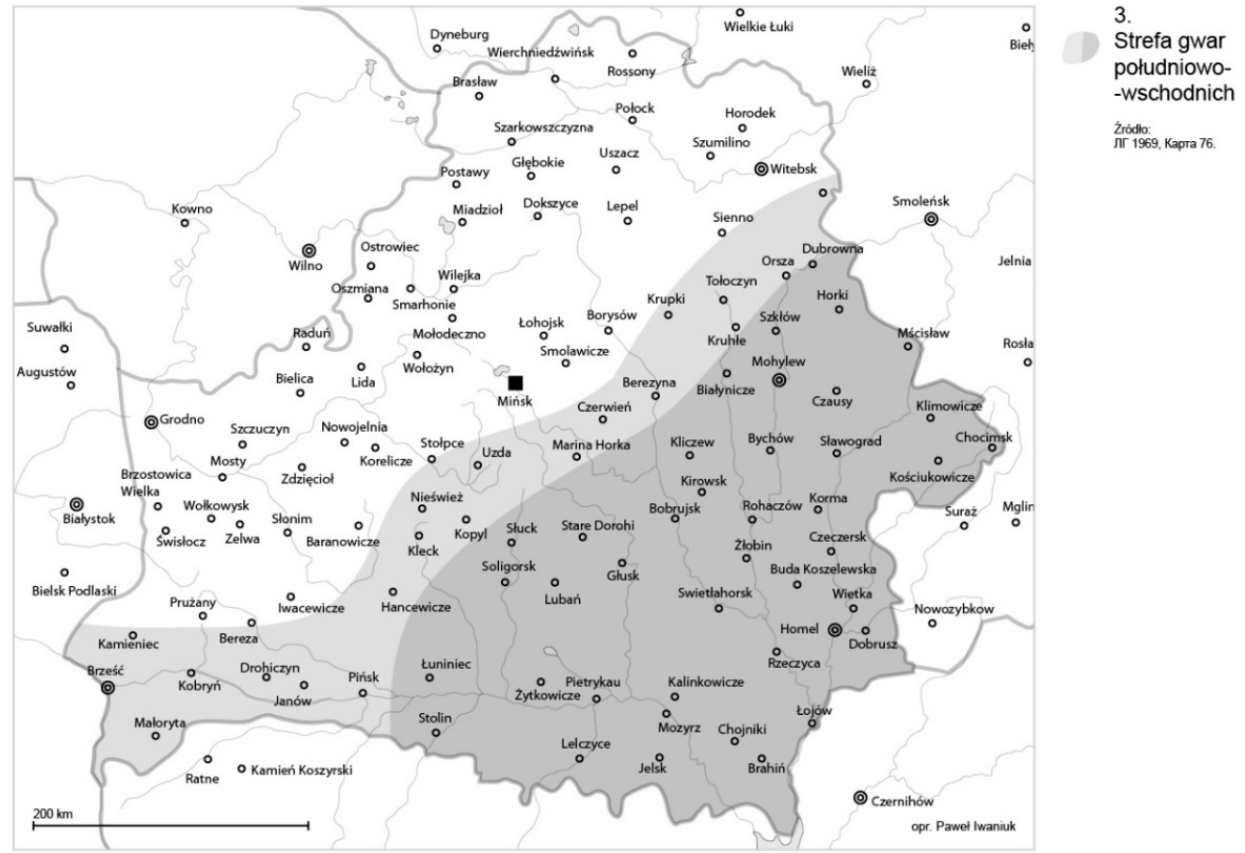

Mapa 3. Zasięg występowania cech typowych dla strefy południowo-zachodniej (Źródło: Barszczewska \& Jankowiak, 2012, s. 231)

W zakresie leksyki typowymi są tu m.in. takie słowa jak: pauz 'wzdłuż, przez' (np. bieh pauz sad 'biegł przez sad'), kariec 'konewka', kaubuch 'żołądek świni', pahanki 'niejadalne grzyby', Wałasażar 'Wielka Niedźwiedzica', kaszara 'zagroda dla bydła na polu', kubło 'gniazdo', waławacha 'czapla', staryk 'dorzecze 
rzeki', dabrakk 'borowik', krucza 'wir wodny', wałaczyć 'bronować ziemię' i wiele innych (ЛГ, 1969, Карты 34, 35; Крывіцкі, 2003, s. 223; ЛАБНГ, 1993-1998). Część z wymienionych powyżej leksemów jest charakterystyczna dla wschodniej części strefy południowo-wschodniej i swym zasięgiem obejmuje tereny przygraniczne po stronie rosyjskiej i ukraińskiej (Barszczewska \& Jankowiak, 2012, s. 129).

Na uwagę zasługuje również to, że na obszarze występowania strefy południowo-wschodniej zanotowane były przez dialektologów bałtyzmy, pomimo sporej odległości od miejsca funkcjonowania współczesnych języków bałtyckich. Słowa te należy zapewne traktować jako zapożyczenia. W szczególności hydronimy i toponimy dają szereg informacji o bałtyckim substracie na tym terenie. Prawdopodobnym jest, że ziemie te były zamieszkiwane wcześniej przez Bałtów, którzy ulegali stopniowej slawizacji od połowy pierwszego tysiąclecia naszej ery. Białoruska lingwistka, Wiera Astrejka, wylicza m.in. następujące cechy jako najprawdopodobniej bałtyckiego pochodzenia:

- zachowanie dźwięcznych spółgłosek w wygłosie i przed bezdźwięcznymi: chlieb a nie chliep 'chleb', horad a nie horat 'miasto', ło żka a nie łószka 'łyżka';

- przejście (y) w (u) po spółgłoskach wargowych, np. putać 'pytać', zubu 'zęby’;

- formy bezokolicznika czasowników, np. bierahci 'biec', stryhci 'strzyc' (por. lit. formy typu: begti 'biec', sùkti 'kręcić') (Астрэйка, 2009, ss. 19-23) ${ }^{13}$.

$\mathrm{Z}$ innych cech charakterystycznych dla strefy południowo-wschodniej można wymienić m.in.:

- występowanie form dop. zaimków dzierżawczych w lp. na -e: u maje 'u mojej', u twaje 'u twojej';

- formy Narz. przymiotników lp. z nieakcentowaną końcówką - am: z żoltam 'z żółtym';

- forma czasownika 3 os. lp. bez końcówki - $t$ ': jon jo 'on jest';

- występowanie konstrukcji z przyimkiem pauz: bieh pauz sad 'biegł przez sad' (ЛГ, 1968, s. 198).

Jak widać, w odróżnieniu od strefy wschodniej czy zachodniej (które zostaną omówione poniżej) sam fakt występowania szeregu cech fonetycznych i gramatycznych na tym obszarze wskazuje na jej archaiczny charakter.

${ }^{13}$ Autorka podkreśla, że cechy te występowały na badanym obszarze znacznie wcześniej, niż uformowały się dialekty ukraińskie czy rosyjskie, co podkreśla ich bałtyckie pochodzenie. 


\section{Zachodnia strefa dialektalna}

W odróżnieniu od wyżej omówionych stref dwie kolejne - zachodnia i wschodnia - przebiegają południkowo i wyznaczają dosyć wyraźną granicę. Do lat 60. XX wieku była ona niezauważalna, choć lingwiści dostrzegali pewną tendencję w leksyce, tj. większą liczbę polonizmów na zachodzie, a rusycyzmów na wschodzie kraju. Słownictwo to odnosi się zazwyczaj do życia codziennego, bytu mieszkańców wsi i w większości są to stosunkowo młode zapożyczenia z polszczyzny czy też języka rosyjskiego (ЛГ, 1968, s. 277).

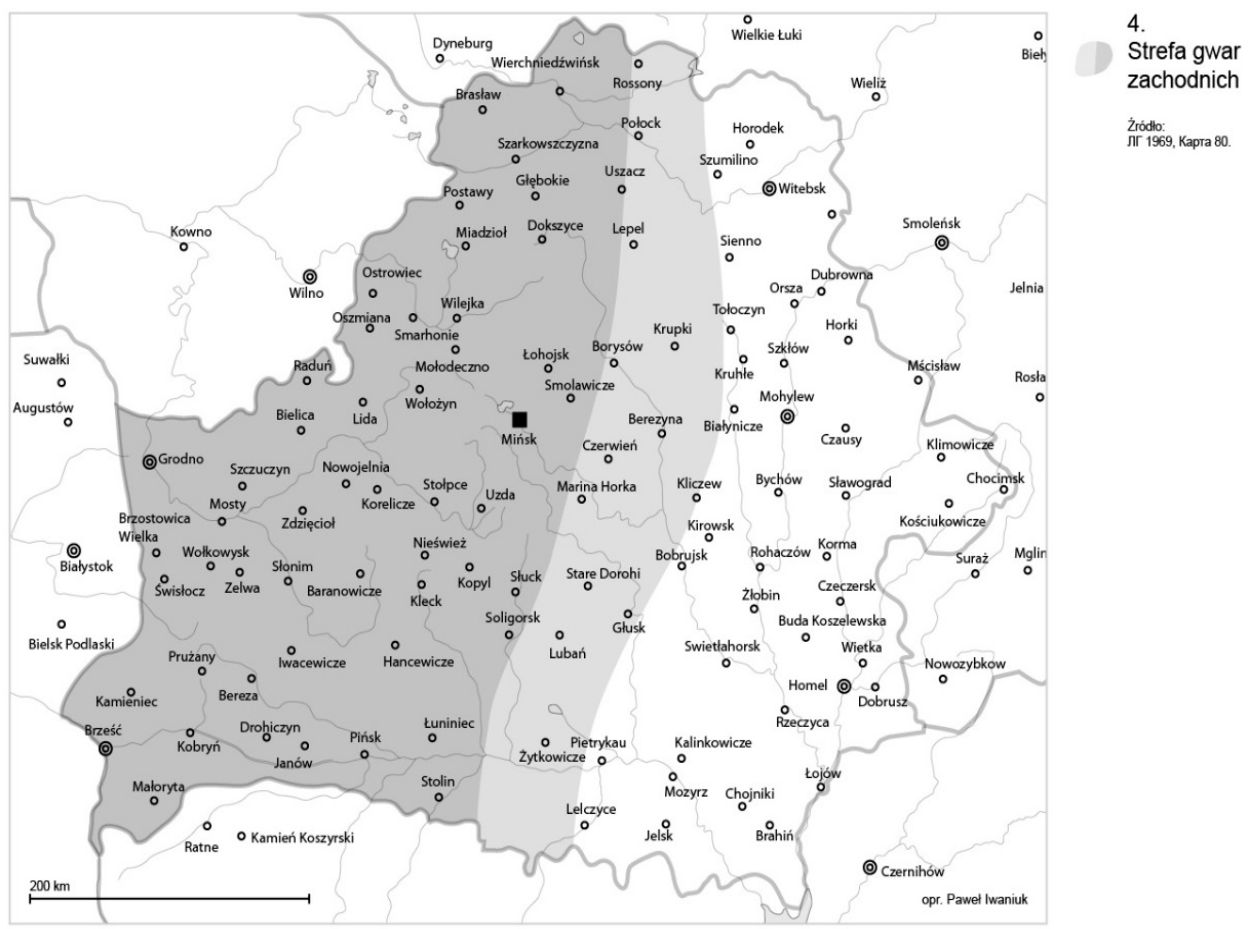

Mapa 4. Zasięg występowania cech typowych dla strefy zachodniej (Źródło: Barszczewska \& Jankowiak, 2012, s. 234)

Granica występowania strefy zachodniej biegnie mniej więcej wzdłuż linii: Rossony - Lepel - Borysów - Marina Horka - Soligorsk - Turów, przy czym niektóre cechy sięgają jeszcze dalej na wschód, nawet po linię: Szumilino - Krugłoje - Kliczów - Bobrujsk - Głusk - Pietryków - Lelczyce (ЛГ, 1969, Карта 80). Granica ta odzwierciedla szereg uwarunkowań historycznych - np. procesów 
osadniczych Polaków na ziemiach białoruskich, zarówno tych dawniejszych (jak Grodzieńszczyzna - już od czasów średniowiecznych ${ }^{14}$ ), okresu Wielkiego Księstwa Litewskiego i I Rzeczypospolitej ${ }^{15}$, jak i bardziej współczesnych przełomu XIX i XX w. (np. w rejonie lepelskim na Witebszczyźnie) ${ }^{16}$.

Kwestia wpływu procesów historycznych na mowę miejscowej ludności nie była do dzisiaj szerzej badana przez dialektologów białoruskich. Nie ulega wątpliwości natomiast to, że duży wpływ na dalsze kształtowanie się tej strefy dialektalnej miał także okres międzywojenny. Zachodnie ziemie białoruskie weszły w skład II Rzeczypospolitej. Polska administracja, polskie szkoły i polski język jako urzędowy oddziaływały także na mowę ludności białoruskiego pochodzenia. Dużą rolę odegrał (i ciągle odgrywa) Kościół katolicki, gdzie w liturgii powszechnie wykorzystuje się polszczyznę (w szczególności na Grodzieńszczyźnie). Z drugiej strony BSRR okresu międzywojennego była silnie językowo, historycznie i kulturowo powiązana ze Związkiem Sowieckim i językiem rosyjskim oddziaływującym także odgórnie - w postaci języka administracji czy edukacji.

Liczne cechy leksykalne pojawiły się zatem jako efekt procesów językowych, a dokładniej pod wpływem języka państwowego i kulturowo-historycznych centrów Białorusi w przeszłości (ЛГ, 1968, s. 305).

Leksyka specyficzna dla zachodniej strefy dialektalnej przeciwstawia się wschodniej - tożsamej z językiem rosyjskim, lub będącej rosyjskimi zapożyczeniami, jak np. rowar (na zachodzie Białorusi) - lisapiet (na wschodzie Białorusi) 'rower', waliska - czamadann 'walizka', zaharak - czasy 'zegarek', wohier - żarabiẹc 'ogier', pszerwa - pieraryu 'przerwa lekcyjna'; ksionżka knihha 'książka'; zesszyt - ciatradz' 'zeszyt', zakkrent - pawarot 'zakręt', pianion$d z y$ - dzienhi 'pieniądze', aliaktrounia - eliektrastancyja 'elektrownia' i wiele innych (ЛГ, 1968, s. 277; Крывіцкі, 2003, s. 225) ${ }^{17}$. Jak widać z przytoczonych powyżej przykładów, praktycznie wszystkie należałoby uznać za zapożyczenia z języka polskiego bądź poprzez polskie medium - przede wszystkim współ-

14 Osadnictwo mazowieckie na ziemiach współczesnej Grodzieńszczyzny historycy datują już na okres średniowiecza.

${ }^{15}$ Na przykład Polesie Zachodnie.

${ }_{16}$ Procesy migracyjne Polaków na ziemie białoruskie (Polesie Zachodnie, Witebszczyzna oraz Mohylewszczyzna) na przełomie XIX i XX wieku zostały szczegółowo opisane w słowniku polskich wysp gwarowych na Białorusi (zob. Pabis, maszynopis).

17 Liczne polonizmy, charakterystyczne dla północno-zachodniej i zachodniej strefy dialektalnej, funkcjonują również w gwarach białoruskich na Litwie (badania własne autora). 
czesne, $\mathrm{z}$ wieku XIX i XX. Liczne polonizmy notowane są również w gwarach białoruskich po litewskiej stronie granicy (badania własne autora).

Zachodnia strefa dialektalna wyróżnia się nie tylko cechami leksykalnymi, lecz także pewnymi cechami fonetycznymi i składniowymi. Wskazywałoby to na fakt, że kształtowała się ona o wiele dłużej niż przez ostatnie kilkadziesiąt lat i jej geneza jest bardziej złożona, choć niewątpliwie nie tak archaiczna jak w przypadku strefy północno-zachodniej czy południowo-wschodniej.

W zakresie fonetyki można wyliczyć następujące cechy:

- realizacja twardych spółgłosek przed samogłoską rzędu przedniego (e) w słowach zapożyczonych: méblia 'meble', szkarpetki 'skarpetki', hazeta 'gazeta', teliefon 'telefon', patelel'nia 'patelnia'. Odnosi się to także do słów typu: serca 'serce', miasteczka 'miasteczko' i nazw geograficznych: Maładéczna (Крывіцкі, 2003, s. 226). Na wschodzie Białorusi leksemy te mają miękkie odpowiedniki typu: cieliefon, haziêta;

- realizacja miękkiego (l') w leksyce obcego pochodzenia, np. halioszy 'kalosze', kliasa 'klasa', hliobus 'globus', kilio 'kilo' i inne;

- realizacja połączeń spółgłosek (čn) i (čń): smaczny 'smaczny', rucznịk 'ręcznik', sonieczny 'słoneczny', jajęcznia 'jajecznica';

- konstrukcje z przyimkiem da, typu: pryjszlí da baćki 'przyszli do ojca', pryjszli da mianie 'przyszli do mnie' oraz konstrukcji z przyimkiem pa, np. pajści pa wadu 'pójść po wodę, pajści pa hryby 'pójść na grzyby' (Крывіцкі, 2003, s. 226); Jak w przypadku leksyki, cechy fonetyczne oraz składniowe typowe dla strefy zachodniej przeciwstawiają się strefie wschodniej.

\section{Wschodnia strefa dialektalna}

Jak wspomniano powyżej, granica zasięgu strefy zachodniej i wschodniej w dużej mierze pokrywa się z granicą II RP z BSRR z okresu międzywojennego. Ziemie białoruskie były jednak podatne na wpływy rosyjskie zdecydowanie dłużej, co najmniej od okresu rozbiorów Rzeczypospolitej. Przez ten czas administracyjna granica nie istniała, a rosyjskie wpływy na ziemiach białoruskich wzmacniały się wraz z napływem administracji carskiej (od czasów carycy Katarzyny II), rosyjskim szkolnictwem oraz coraz bardziej powszechnym na tych ziemiach prawosławiem. Trudno jednoznacznie stwierdzić, że jakaś dawna granica państwowa czy administracyjna aż tak mocno wpłynęła na taki południkowy podział 
ziem białoruskich, skoro w danych czasach nie funkcjonowały byty państwowe, których granice etniczno-językowe pokrywałyby się z zasięgiem występowania strefy zachodniej i wschodniej. Wyjątkiem jest tylko okres międzywojenny.

Zasięg występowania wschodniej strefy dialektalnej języka białoruskiego wyznaczają następujące miejscowości: na wschód od Wierchniedźwińska Dokszyce - na zachód od Mińska - Kopyl - Mikaszewicze. Niektóre cechy sięgają nawet po linię Brasław - Miadzioł - Wilejka - Mołodeczno - Stołpce, a dalej na wschód od Soligorska (ЛГ, 1969, Карта 79).

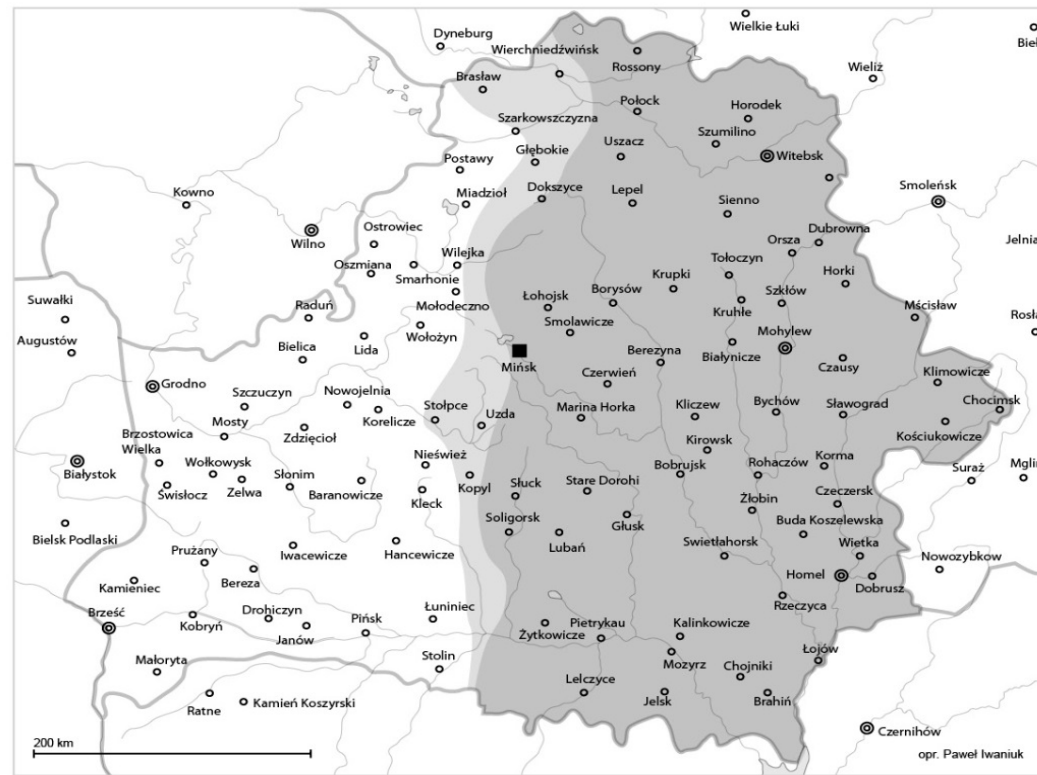

5 .

Strefa gwar wschodnich Żródlo:
Лг 1969, Kapra 79.

Mapa 5. Zasięg występowania cech typowych dla strefy wschodniej (Źródło: Barszczewska \& Jankowiak, 2012, s. 233)

Największą grupę leksemów, których zasięg wyznacza linia północ-południe, dzieląca tym samym Białoruś na część zachodnią i wschodnią, stanowią te, które przeciwstawiają się leksyce zachodniej. Część przykładów została przytoczona już powyżej, poniżej kolejne: kawal' (na zachodzie) - kuźniẹc (na wschodzie) 'kowal' (ДАБМ, 1963, Карта 314), chwory - bal'ny (ДАБМ, 1963, Карта 319), haspadar - chaziain 'gospodarz' (ДАБМ, 1963, Карта 334), ziaziulia - kukuszka 'kukułka' (ДАБМ, 1963, Карта 309), chustka - płatok 'chusta' (ДАБМ, 1963, Карта 332), spadnica - jubka 'spódnica' (ДАБМ, 1963, Карта 329), wiasiell'lie - swadźba 'wesele' (ДАБМ, 1963, Карта 338), irwać 
(len) - brać (len) 'rwać len' (ДАБМ, 1963, Карта 267), padłoha - pamost / most 'podłoga' (ДАБМ, 1963, Карта 336), świ rin - ambar 'budynek do przechowywania zboża' (ЛГ, 1969, Карта 67; ДАБМ, 1963, Карта 239). Izoglosy niektórych leksemów wyznaczają bardzo wyraźną granicę rozdzielającą wschód od zachodu (jak rwać len, podłoga), w przypadku innych granica jest rozmyta, $\mathrm{z}$ obszarem przejściowym (na którym funkcjonują z różną częstotliwością oba warianty - zachodni i wschodni), jak np. kowal, chory, kukułka.

Jak w przypadku innych stref, tak też w strefie wschodniej leksyka może być dwojakiego charakteru - jako wynik kontaktu dwóch sąsiadujących ze sobą dialektów albo efekt nakładania się języka (np. urzędowego, powszechnego w mediach) na dialekt. To, do jakiej grupy należy dany leksem, widać po jego rozpowszechnieniu na danym terytorium. Jeżeli jedno słowo obejmuje cały obszar, to zapewne jest to interferencja język $\leftrightarrow$ dialekt, jeżeli z kolei istnieje obszar przejściowy (gdzie dwa różne leksemy występują na jakimś obszarze i zauważalna jest zmiana częstotliwości im bardziej przemieszczamy się na zachód / wschód), to jest to efekt ścierania się w przeszłości dwóch dialektów. $\mathrm{W}$ drugim przypadku, tj. kontaktu dialekt-dialekt, będą to np. leksemy określające podłogę i obrus. Przykładem zapożyczenia jest spódnica - na zachodzie spadnica, na wschodzie rosyjska jubka.

W zakresie fonetyki i składni widoczne są następujące cechy:

- miękka wymowa spółgłosek w słowach obcego pochodzenia, typowa dla języka rosyjskiego, np. awanciura 'awantura', dzirektar 'dyrektor', uniwiersiciet 'uniwersytet', mie biel' 'meble', miascięczka 'miasteczko', Maładzięczna 'Mołodeczno', sierca 'serce';

- realizacja połączeń spółgłosek (šn) i (šń): smassnyy 'smaczny', rusznịk 'ręcznik', jajessznia 'jajecznica', pahranissznik 'pogranicznik';

- realizacja wargowego (f) w słowach zapożyczonych: na zachodzie jako (f) albo (p), a na wschodzie jako (chw), (kw) albo (ch), np. fasolia, pasol' : kwasolia, chwasolia, chasol' 'fasola' (ЛГ, 1969, Карта 65; ДАБМ, 1963, Карта 44);

- realizacja zaimka wskazującego 'ten' - jety / jeny na wschodzie Białorusi wobec zachodniego hety / heny (ЛГ, 1969, Карта 65; ДАБМ, 1963, Карта 49);

- konstrukcje z przyimkiem $k$, typu: pajechau $k$ siastrie, pajechau $k$ dzirie $\underline{\text { en- }}$ taru 'pojechał do siostry / dyrektora', z przyimkiem za: schadzíu za wadoj, za hrybami 'poszedł po wodę / na grzyby' (Крывіцкі, 2013, s. 227);

- konstrukcje typu: mnie balić haława - u mianie balić haława 'boli mnie głowa' (ДАБМ, 1963, Карта 223). 


\section{Centralna strefa dialektalna}

Ze wszystkich pięciu stref centralna należy do najmniej wyraźnych i sprawia największe trudności przy jej scharakteryzowaniu. Jednocześnie pełne jej zrozumienie jest niezwykle ważne $\mathrm{z}$ punktu widzenia formowania się białoruskiego języka literackiego, a zatem także tożsamości narodu białoruskiego (Крывіцкі, 2003, ss. 227, 228). Szereg cech specyficznych dla strefy centralnej jest także właściwych białoruskiemu językowi literackiemu.

Granica tej strefy w dużej mierze jest wypadkową kształtowania się północno-wschodniego oraz południowo-zachodniego dialektu języka białoruskiego. Granicę północno-wschodnią wyznaczają w przybliżeniu miejscowości: Postawy - na wschód od Dokszyc - Borysów - Białynicze - Bychów - Czeczersk, południowo-zachodnią z kolei: Próżany - Iwacewicze - Hancewicze - Kalinkowicze. Jak w przypadku pozostałych stref dialektalnych, również pewne cechy strefy centralnej sięgają znacznie dalej poza wskazaną powyżej granicę - na północnym-wschodzie po linię: Szarkowszczyzna - Lepel - Tołoczyn - Mohy-

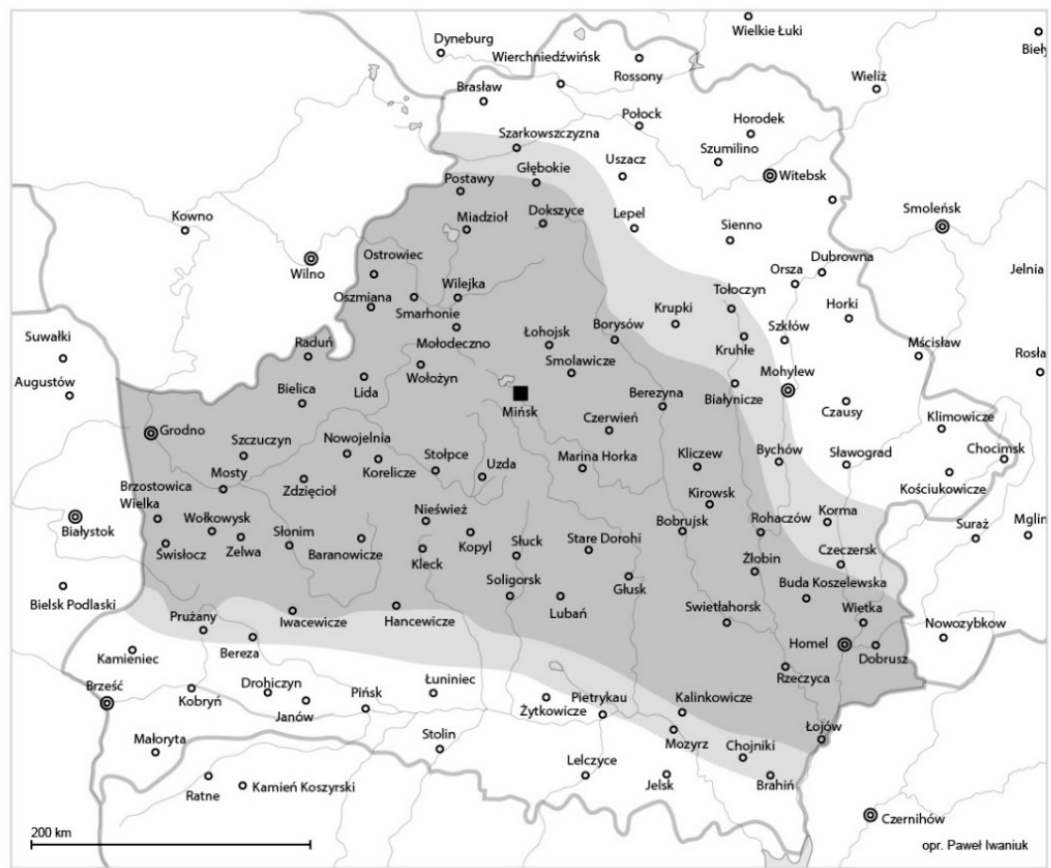

Mapa 6. Zasięg występowania cech typowych dla strefy centralnej (Źródło: Barszczewska \& Jankowiak, 2012, s. 235) 
lew - na południe od Sławogradu; natomiast linię południowo-zachodnią tworzą: Bereza - Pietrykau - Mozyrz - Brahiń (ЛГ, 1969, Карта 78).

$\mathrm{Z}$ cech charakterystycznych dla centralnej strefy można wymienić następujące (ЛГ, 1968, 199; Крывіцкі, 2003, ss. 228, 229):

- niedysymilatywne akanie typu: wada - wady 'woda', trawa - trawy 'trawa'18 (ЛГ, 1969, Карта 64; ДАБМ, 1963, Карта 1, 8, 9, 12, 13);

- występowanie tylko twardego (r): horad 'miasto', kuryćc 'palić (papierosa)', ręzać 'obcinać, ciąć' (ЛГ, 1969, Карта 64; ДАБМ, 1963, Карта 42);

- występowanie protetycznych (h) i (w): hety 'ten', wożyk 'mały wąż';

- postać Mian. przymiotników w lp. r.m. (bez wygłosowego (j)): małady 'młody', nowy 'nowy', sini 'niebieski' (ЛГ, 1969, Карта 64; ДАБМ, 1963, Карта 110, 111);

- przewaga końcówki -au, -iau rzeczowników w Dop. lm.: chatau 'domów, chat', ściennau 'ścian', pieśniau 'pieśni' (ЛГ, 1969, Карта 64; ДАБМ, 1963, Карта 101);

- produktywny sufiks -ica: buślica 'bocianica', łasica 'łasica', tcharyca 'tchórzyca', miadźwiędzica 'niedźwiedzica';

- postać Mian. zaimka 'uwieś: usie 'wszyscy, wszystkie, wszystek' (ЛГ, 1969, Карта 64; ДАБМ, 1963, Карта 141).

Zarówno gwary środkowobiałoruskie, jak i strefa centralna to wynik interferencji cech dialektu północno-wschodniego z południowo-zachodnim, a z czasem wykształcenia się cech specyficznych tylko dla tego obszaru. W okresie formowania się współczesnego narodu białoruskiego (przełom XIX i XX wieku) i współczesnego białoruskiego języka literackiego gwary tej części Białorusi zaczęły odgrywać decydującą rolę, z czego zdawali sobie sprawę np. pisarze, traktując je jako wzór przy pisaniu tekstów literackich (Крывіцкі, 2003, ss. 229, 230). Największa aktywność białoruskich pisarzy i działaczy społeczno-politycznych na przełomie XIX i XX wieku przypadła geograficznie na historyczną Wileńszczyznę - przede wszystkim Wilno oraz pomniejsze okoliczne miasteczka, czyli terytorium najbardziej zróżnicowane etnicznie i językowo. Formowanie się białoruskiego języka literackiego na północnym-zachodzie wynikało zatem $\mathrm{w}$ dużej mierze $\mathrm{z}$ kulturowo-historycznych

18 Przy akaniu dysymilatywnym (typowym dla wschodniej Białorusi) samogłoski (a), (e) znajdujące się przed sylabą z akcentowaną samogłoską (a) uległyby zredukowaniu: woda , trowa . 
kontaktów z polszczyzną i językiem litewskim. Z czasem głównym centrum białoruskości stał się jednak Mińsk, odsuwając historyczne Wilno na dalszy plan. Spowodowało to wzbogacenie języka literackiego o leksykę typową dla gwar okolic Mińska, co jednocześnie oznaczało „uwolnienie się” od licznych polonizmów i lituanizmów obecnych w mowie mieszkańców Wilna i okolic (Крывіцкі, 2009, ss. 507-510). Centralna strefa języka białoruskiego różni się od pozostałych tym, że charakteryzuje się podwójną specyfiką - innowacjami będącymi efektem międzydialektalnej kontaminacji oraz będącymi efektem procesów społeczno-kulturowych, ale wynikających nie z kontaktu z narodami sąsiednimi, lecz z relacji wewnątrzbiałoruskich (Крывіцкі, 2009, ss. 512, 513).

\section{Strefy dialektalne wobec dialektów języka białoruskiego}

Porównanie dialektów i grup dialektalnych ze strefami dialektalnymi uwidacznia szereg różnic, w odniesieniu zarówno do struktury czy genezy, jak i do roli w kształtowaniu się białoruskiego narodu i białoruskiego języka literackiego:

- tradycyjny podział wskazuje na etnogenetyczną wspólnotę narodu i języka białoruskiego (ogólne, wspólne cechy dla białoruszczyzny). Odzwierciedla rolę dawnych plemion w kształtowaniu się dwóch głównych masywów dialektalnych (północno-wschodniego: Krywicze i Radymicze oraz południowo-zachodniego: Dregowicze). Strefy dialektalne to z kolei przetransformowane dawne etnogenetyczne grupy gwar uzupełnione o innowacje powstałe $\mathrm{w}$ wyniku kontaktu $\mathrm{z}$ językami narodów sąsiednich (wówczas plemion / grup etnicznych). W strefach dialektalnych odzwierciedlają się zatem kulturowo-historyczne związki - strefa północno-zachodnia z językiem litewskim, łotewskim i polskim; strefa zachodnia $\mathrm{z}$ językiem polskim, wschodnia - rosyjskim i południowo-wschodnia - ukraińskim i rosyjskim. Cechy typowe dla języków sąsiednich nakładają się zatem na tradycyjne dialekty i grupy gwarowe. Dialekty i grupy gwarowe stanowią niejako „zamknięty” areał, gdzie w pierwszej kolejności zachodzą procesy językowe w ramach białoruszczyzny, a strefy dialektalne - areał „otwarty”;

- tradycyjne dialekty przeciwstawiają się sobie cechami fonetyczno-gramatycznymi - dialekt północno-wschodni (charakteryzujący się cechami wspólnymi z gwarami zachodniorosyjskimi) wobec południowo-zachodniego (związki z gwarami północnoukraińskimi). Strefy dialektalne są 
dowodem na wspólnotę leksykalną obydwu dialektów oraz na związki leksykalne z gwarami i językami narodów sąsiednich;

- tradycyjny podział na dialekty i gwary odbywa się w oparciu o cechy fonetyczne i gramatyczne (najbardziej stabilne poziomy struktury gwary) i ukazuje wszystkie poziomy struktury, a strefy gwarowe zazwyczaj tylko leksykę, która jest najbardziej podatna i otwarta na wpływy zewnętrzne. Na przykładzie stref dialektalnych widać zatem swoistego typu „postkolonializm” bałtycki, polski i rosyjski, odzwierciedlający się właśnie w słownictwie miejscowych gwar białoruskich $^{19}$. Jest on efektem migracji ludności (narodów sąsiednich), zmian granic administracyjnych, rządów, charakteru gospodarki, procesów kulturowych etc. Leksyka była uzupełniana o zapożyczenia w sytuacji, gdy brakowało własnych nazw na określenie nowych przedmiotów czy nowej otaczającej rzeczywistości. Dlatego też słownictwo odzwierciedla związki kulturowe czy gospodarcze między przodkami Białorusinów a narodami sąsiadującymi.

\section{Perspektywy badawcze stref dialektalnych}

Ze względu na swój charakter (uwidaczniający się w leksyce i reprezentujący tylko wycinek struktury mowy) strefy dialektalne nie są uważane za komponent języka białoruskiego, nie zmieniają też ogólnego charakteru dialektów białoruskich czy ich przynależności do takiego czy innego języka, a dodają tylko dodatkowy „odcień" o pozadialektalnym charakterze. Dostrzeżenie takiego dodatkowego podziału dialektów białoruskich ma ogromne znaczenie nie tylko poznawcze, lecz także metodologiczno-teoretyczne. Umożliwia prawidłowe strukturalno-terytorialne interpretowanie podziału gwar białoruskich, a przede wszystkim ich związków $\mathrm{z}$ sąsiednimi językami. Analiza izoglos, które zostały nakreślone dzięki ДАБМ, a także w najnowszych pracach dialektologów, może pokazywać nie tylko dawne strefy (które istniały), lecz także powstające właśnie nowe innowacje, z których mogą wyłonić się nowe strefy dialektalne (Крывіцкі, 2003, ss. 215, 216).

Leksykalne izoglosy można traktować jak granicę językowej albo dialektalnej interferencji, przy czym interferencja może mieć dwojaki charakter - bezpośredni kontakt sąsiadujących ze sobą dialektów lub grup gwarowych (coraz

$19 \mathrm{Na}$ podstawie rozmowy z Weroniką Kurcową, kierownikiem Działu Dialektologii Centrum Badań nad Białoruską Kulturą, Językiem i Literaturą Narodowej Akademii Nauk Białorusi, sierpień 2013. 
mniejsze znaczenie) lub wpływu języka na gwary białoruskie (coraz częstsze). Zachodzące w ostatnich kilkudziesięciu latach (czyli akurat od „odkrycia” stref dialektalnych w latach 60 . XX wieku) zmiany wynikające z globalizacji, dostępności edukacji i powszechności mediów (głównie rosyjskojęzycznych) powodują zmianę struktury gwar także na poziomie idiolektalnym. Dotyczy to zarówno centrum Białorusi, jak i pograniczy. Potwierdzają to liczne badania terenowe przeprowadzone w ostatnich latach ${ }^{20}$.

Niewątpliwie największe wyzwanie $\mathrm{w}$ dalszych badaniach może stanowić bardzo wysoki poziom idiolektalności gwar, co będzie także rzutować na zakres funkcjonowania stref dialektalnych, a przede wszystkim na metodologiczne podejście do ich badań. Naukowcy coraz częściej zwracają uwagę, że nie można już mówić o gwarze na danym obszarze, a raczej o „mowie” mieszkańców pogranicza. W odniesieniu do białoruskojęzycznego obszaru zwróciła na to uwagę Elżbieta Smułkowa, wysuwając koncepcję mowy pogranicza. Badaczka podkreśla, że w wypowiedziach wielojęzycznych osób następuje „mieszanie się” leksyki. Powstaje zatem na poziomie idiolektalnym zasób leksyki wspólnej, zrozumiałej dla wszystkich, choć pochodzącej z różnych języków (tutaj: białoruski, litewski, polski, rosyjski) (zob. szerzej: Smułkowa, 2011b, ss. 101-140). Takie rozumienie mowy pogranicza $\mathrm{w}$ pewnym sensie nawiązuje do stref dialektalnych - w tym konkretnym przypadku do strefy północno-zachodniej. Do koncepcji mowy pogranicza nawiązują również inni badacze, zajmujący się nie tylko białoruszczyzną, ale w ogóle sytuacją wielojęzyczności, jak np. Anna Zielińska (Zielińska, 2013, ss. 62-67).

Metody stosowane w geografii lingwistycznej (która dała początek badaniom nad strefami dialektalnymi) nie umożliwiają niestety dokładniejszego określenia, kiedy zaszły procesy dające początek funkcjonowaniu takiej czy innej strefy. Można wprawdzie przyjąć, że granica izoglos to początek dyferencjacji, pierwszy etap tworzenia się po obu stronach granicy dwóch oddzielnych jednostek dialektalnych. Granica dialektalna to z kolei zakończenie procesu dyferencjacji, powstanie dialektu jako oddzielnej struktury dialektalnej. Na początku tego procesu znalazły się np. strefy zachodnia i wschodnia. Gdyby podział administracyjny sprzed 1939 roku istniał dalej, następowałoby dalsze ich kształtowanie się

20 Wiele interesujących aspektów ukazują materiały zebrane w trakcie badań terenowych na pograniczach Białorusi, jak np. te zaprezentowane w artykułach zamieszczonych w książce Pogranicza Białorusi w perspektywie interdyscyplinarnej, wydanej pod red. E. Smułkowej i A. Engelking (2007), monografii o gwarach białoruskich na Łotwie (Jankowiak, 2009) czy wspomniana już wyżej zbiorowa praca pod red. E. Smułkowej $(2009,2011 a)$. 
i wzmacnianie podziału wschód-zachód, jednak obecnie następuje unifikacja zachodniej Białorusi z jej wschodnią częścią za sprawą nie tylko przynależności do jednej państwowości (państwo białoruskie), lecz także powszechnej rusyfikacji odbywającej się na wielu poziomach (ЛГ, 1968, ss. 305, 306).

Szybkie zmiany polityczne, globalizacja i intensywna rusyfikacja powodują, że niezbędnym byłoby zebranie nowego materiału dialektalnego ze wszystkich pograniczy i porównanie go z materiałami sprzed 50 lat. Można założyć, że obecnie następuje proces unifikacji masywów dialektalnych i stref dialektalnych w związku z „odgórną" rusyfikacją, powolne zanikanie podziału południkowego na strefę zachodnią i wschodnią (ogromna rola języka rosyjskiego i słabnące wpływy polszczyzny), zanikanie strefy południowo-wschodniej (jako charakteryzującej się licznymi cechami archaicznymi, które wychodzą z użycia). Niewątpliwie najciekawsza pod względem badawczym jest strefa północno-zachodnia - jej zbadanie wymaga jednak dokładnego zapoznania się z najnowszym materiałem, co będzie tematem już kolejnego artykułu ${ }^{21}$.

\section{Bibliografia}

Barszczewska, N., \& Jankowiak, M. (2012). Dialektologia białoruska. Warszawa: Slawistyczny Ośrodek Wydawniczy.

Birgiel, N. (2011). Język litewski na Białorusi. W: E. Smułkowa (Red.), Brasławszczyzna: Pamięć i współczesność (T. 1, Historia regionu. Charakterystyka socjolingwistyczna. Świadectwo mieszkańców, ss. 184-206). Warszawa: Wydawnictwa Uniwersytetu Warszawskiego.

Budźko, I. (2011). Gwary białoruskie rejonu brasławskiego: Geneza, geografia, uwarunkowania socjolingwistyczne. W: E. Smułkowa (Red.), Brasławszczyzna: Pamięć i współczesność (T. 1, Historia regionu. Charakterystyka socjolingwistyczna. Świadectwo mieszkańców, ss. 141-171). Warszawa: Wydawnictwa Uniwersytetu Warszawskiego.

Guszczewa, O. (2011). Zakres użycia języka rosyjskiego i jego oddziaływanie na gwary białoruskie i polszczyznę w rejonie brasławskim. W: E. Smułkowa (Red.), Brasławszczyzna: Pamięć $i$ współczesność (T. 1, Historia regionu. Charakterystyka socjolingwistyczna. Świadectwo mieszkańców, ss. 214-246). Warszawa: Wydawnictwa Uniwersytetu Warszawskiego.

21 Autor zebrał już sporo własnych materiałów z obszaru występowania strefy północno-zachodniej, zachodniej i wschodniej: południowa Pskowszczyzna, łotewska Łatgalii oraz Wileńszczyzna, co w porównaniu z materiałami białoruskich dialektologów, zebranymi po białoruskiej stronie granicy, wskazuje na żywe procesy mające miejsce w tych strefach dialektalnych. 
Jankowiak, M. (2007). Zakres funkcjonowania języka białoruskiego i stan zachowania gwary na przykładzie wybranych miejscowości w okolicach Horek w obwodzie mohylewskim. W: E. Smułkowa \& A. Engelking (Red.), Pogranicza Białorusi w perspektywie interdyscyplinarnej (ss. 293-315). Warszawa: Wydawnictwo DiG.

Jankowiak, M. (2009). Gwary białoruskie na Łotwie w rejonie krasławskim: Studium socjolingwistyczne. Warszawa: Slawistyczny Ośrodek Wydawniczy.

Kuryan, I. (2011). Charakterystyka idiolektów języka polskiego. W: E. Smułkowa (Red.), Brasławszczyzna: Pamięć i współczesność (T. 1, Historia regionu. Charakterystyka socjolingwistyczna. Świadectwo mieszkańców, ss. 184-206). Warszawa: Wydawnictwa Uniwersytetu Warszawskiego.

Kuraszkiewicz, W. (1963). Zarys dialektologii wschodniosłowiańskiej: Z wyborem tekstów gwarowych (2. wyd.). Warszawa: Państwowe Wydawnictwo Naukowe.

Pabis, I. (2011). Staroobrzędowcy - inni Rosjanie. W: E. Smułkowa (Red.), Brasławszczyzna: Pamięć i współczesność (T. 1, Historia regionu. Charakterystyka socjolingwistyczna. Świadectwo mieszkańców, ss. 207-213). Warszawa: Wydawnictwa Uniwersytetu Warszawskiego.

Pabis, I. (b.d.). Polskie wyspy gwarowe przełomu XIX i XX wieku na Białorusi (ze słownikiem). Maszynopis.

Rieger, J. (2014). Słownictwo polszczyzny gwarowej na Brasławszczyźnie. Warszawa: Uniwersytet Warszawski, Wydział „Artes Liberales”.

Smułkowa, E. (Red.). (2009). Brasławszczyzna: Pamięć i współczesność (T. 2, Słownictwo dwujęzycznych mieszkańców rejonu (Słownik brasławski)). Warszawa: Wydawnictwa Uniwersytetu Warszawskiego.

Smułkowa, E. (Red.). (2011a). Brasławszczyzna: Pamięć i współczesność (T. 1, Historia regionu. Charakterystyka socjolingwistyczna. Świadectwo mieszkańców). Warszawa: Wydawnictwa Uniwersytetu Warszawskiego.

Smułkowa, E. (2011b). Sytuacja socjolingwistyczna i proces konwergencji języków na Brasławszczyźnie w świetle badań terenowych (1997-2007). W E. Smułkowa (Red.), Brasławszczyzna: Pamięć i wspótczesność (T. 1, Historia regionu. Charakterystyka socjolingwistyczna. Świadectwo mieszkańców, ss. 101-140). Warszawa: Wydawnictwa Uniwersytetu Warszawskiego.

Smułkowa, E., \& Engelking, A. (Red.). (2007). Pogranicza Białorusi w perspektywie interdyscyplinarnej. Warszawa: Wydawnictwo DiG.

Thomason, S. (2001). Language contact: An introduction. Edinburgh: Edinburgh University Press.

Zielińska, A. (2013). Mowa pogranicza: Studium o językach i tożsamościach w regionie lubuskim. Warszawa: Slawistyczny Ośrodek Wydawniczy.

Аванесаў, Р. І., Атраховіч, К. К., \& Мацкевіч, Ю. Ф. (Red.). (1968). Лінгвістычная геаграббія і групоўка беларускіх гаворак [ЛГ]. Мінск: Навука і тэхніка. (Książka).

Аванесаў, Р. І., Атраховіч, К. К., \& Мацкевіч, Ю. Ф. (Red.). (1969). Лінгвістычная геаграфбія і групоўка беларускіх гаворак [ЛГ]. Мінск: Навука і тэхніка. (Atlas).

Аванесаў, Р. І., Крапіва, К. К., \& Мацкевіч, Ю. Ф. (Red.). (1963). Дыялекталагічны атлас беларускай мовы [ДАБМ]. Мінск: Выдавецтва Акадэмія навук БССР.

Астрэйка, В. (1998). Паўночна-заходняя занальная лексіка іншамоўнага паходжання. Беларуская Лінгвістыка, 48, 51-55. 
Астрэйка, В. (2006а). Северная группа белорусских говоров как одна из зон межъязыкового взаимодействия. W: Proceedings of the 4th International Congress of Dialectologists and Geolinguists (ss. 25-31). Rìga: Latvian Language Institute, University of Latvia.

Астрэйка, В. (2006b). Формирование юго-восточной диалектной зоны белорусского языка в контексте проблемы этноязыкового взаимодействия. W: Путь к родному слову: Сб. науч. ст. к 60-летию проф. Р. И. Кудряшовой (ss. 76-78). Волгоград: Перемена.

Астрэйка, В. (2008). Балцкі моўны элемент у гаворках паўднёва-ўсходняй дыялектнай зоны беларускай мовы. W: Дыялекталогія і гісторыя беларускай мовы: Матэрыялы міжнароднай навуковай канферэнщыл, Мінск 15-16 красавіка 2008 г. (ss. 86-91). Мінск: Права і эканоміка.

Астрэйка, В. (2009). Паўднёва-усходняя дыялектная зона беларускай мовы і славяна-балцкія кантакты і сувязі. Беларуская Лінгвістыка, 63, 18-25.

Астрэйка, В. (2010а). Балцкі субстрат ў гаворках асноўных дыялектных зон беларускай мовы. W: J. Mędelska \& Z. Sawaniewska-Moch (Red.), Językowe i kulturowe dziedzictwo Wielkiego Księstwa Litewskiego: Księga jubileuszowa na 1000-lecie Litwy (ss. 180-186). Bydgoszcz: Wydawnictwo Uniwersytetu Kazimierza Wielkiego.

Астрэйка, В. (2010b). Славяна-балцкае лексічнае ўзаемадзеянне ў гаворках паўночна-заходняй дыялектнай зоны беларускай мовы. Беларуская Лінгвістыка, 65, 11-19.

Астрэйка, В. (2012). Асаблівасці польскага моўнага ўплыву на фанетыку і граматыку традыцыйных мясцовых гаворак паўночнага захаду Беларусі. Rozprawy Komisji Językowej ŁTN, 58, 15-25.

Гуліцкая, В. А., Гуліцкі, М. Ф., Злобін, Л. І., \& Рудакоўская, З. А. (1992). Беларуская і руская дыялекталогія. Мінск: Вышэйшая школа.

Блінава, Э., \& Мяцельская, Е. (1980). Беларуская дыялекталогія. Мінск: Вышэйшая школа.

Будзько, І. (2007). Лінгвістычны і сацыялінгвістычны характар беларускага памежжа: Да пастаноўкі праблемы. W E. Smułkowa \& A. Engelking (Red.), Pogranicza Białorusi w perspektywie interdyscyplinarnej (ss. 259-280). Warszawa: Wydawnictwo DiG.

Захарова, К. Ф., \& Орлова, В. Г. (1970). Диалектное членение русского языка. Москва: Издательство „Просвещение”.

Касаткин, Л. Л. (Red.). (2005). Русская диалектология. Москва: Издательский центр „Академия”. Крывіцкі, А. А. (2003). Дыялекталогія беларускай мовы. Мінск: Выдавецтва „Вышэйшая школа”. Крывіцкі, А. А. (2009). Беларуская нацыянальная моватворчасць і сярэдняя (цэнтральная) дыялектная зона беларускай мовы. W: Л. П. Кунцэвіч \& B. M. Курцова (Red.), Хрэстаматыя па беларускай дыялекталогіi. Цэнтральная зона (ss. 507-513). Мінск: Беларуская навука.

Кунцэвіч, Л. П., \& Курцова, В. М. (Red.). (2009). Хрэстаматыя па беларускай дыялекталогіi: Цэнтральная зона. Мінск: Беларуская навука.

Лексічны атлас беларускіх народных гаворак [ЛАБНГ]. (1993-1998). Мінск: Інстытут Мовазнаўства імя Якуба Коласа, Акадэмія навук Беларусі.

Эркер, А. (2015). Структурные черты смешанных белорусских говоров на балто-славянском пограничье. Mainz: Kubon \& Sagner. (Slavolinguistica, 22). 


\section{Bibliography (Transliteration)}

Astrèrka, V. (1998). Paŭnochna-zakhodniaia zanal'naia leksika inshamoŭnaha pakhodzhannia. Belaruskaia Linhvistyka, 48, 51-55.

Astrěka, V. (2006a). Severnaia gruppa belorusskikh govorov kak odna iz zon mezh'iazykovogo vzaimoderstviia. In Proceedings of the 4th International Congress of Dialectologists and Geolinguists (pp. 25-31). Riga: Latvian Language Institute, University of Latvia.

Astrëĭka, V. (2006b). Formirovanie iugo-vostochnoŭ dialektnoŭ zony belorusskogo iazyka v kontekste problemy ètnoiazykovogo vzaimodeĭstviia. In Put' k rodnomu slovu: Sb. nauch. st. k 60-letiiu prof. R. I. Kudriashovoŭ (pp. 76-78). Volgograd: Peremena.

Astrèkka, V. (2008). Baltski moŭny èlement u havorkakh paŭdnëva-ŭskhodniaŭ dyialektnaŭ zony belaruskaŭ movy. In Dyialektalohiia i historyia belaruskă̌ movy: Matéryialy mizhnarodnaĭ navukovaĭ kanferèntsyi, Minsk 15-16 krasavika 2008 h. (pp. 86-91). Minsk: Prava i èkanomika.

Astrèĭka, V. (2009). Paŭdnëva-uskhodniaia dyialektnaia zona belaruskaŭ movy i slaviana-baltskiia kantakty i suviazi. Belaruskaia Linhvistyka, 63, 18-25.

Astrèĭka, V. (2010a). Baltski substrat ŭ havorkakh asnoŭnykh dyialektnykh zon belaruskaŭ movy. In J. Mędelska \& Z. Sawaniewska-Moch (Eds.), Językowe i kulturowe dziedzictwo Wielkiego Księstwa Litewskiego: Księga jubileuszowa na 1000-lecie Litwy (pp. 180-186). Bydgoszcz: Wydawnictwo Uniwersytetu Kazimierza Wielkiego.

Astrëka, V. (2010b). Slaviana-baltskae leksichnae ŭzaemadzeianne ŭ havorkakh paŭnochna-zakhodniaŭ dyialektnaĭ zony belaruskaŭ movy. Belaruskaia Linhvistyka, 65, 11-19.

Astrèika, V. (2012). Asablivastsi pol'skahamoŭnaha ŭplyvu na fanetyku i hramatyku tradytsyı̆nykh miastsovykh havorak paŭnochnaha zakhadu Belarusi. Rozprawy Komisji Językowej ŁTN, $58,15-25$.

Avanesaŭ, R. I., Atrakhovich, K. K., \& Matskevich, I. F. (Eds.). (1968). Linhvistychnaia heahrafiia i hrupoŭka belaruskikh havorak [LH]. Minsk: Navuka i tèkhnika. (Book).

Avanesaŭ, R. I., Atrakhovich, K. K., \& Matskevich, I. F. (Eds.). (1969). Linhvistychnaia heahrafiia i hrupoǔka belaruskikh havorak [LH]. Minsk: Navuka i tèkhnika. (Atlas).

Avanesaŭ, R. I., Krapiva, K. K., \& Matskevich, I. F. (Eds.). (1963). Dyialektalahichny atlas belaruskă̌ movy [DABM]. Minsk: Vydavetstva Akadėmiia navuk BSSR.

Barszczewska, N., \& Jankowiak, M. (2012). Dialektologia białoruska. Warszawa: Slawistyczny Ośrodek Wydawniczy.

Birgiel, N. (2011). Język litewski na Białorusi. In E. Smułkowa (Ed.), Brasławszczyzna: Pamięć i współczesność (Vol. 1, Historia regionu. Charakterystyka socjolingwistyczna. Świadectwo mieszkańców, pp. 184-206). Warszawa: Wydawnictwa Uniwersytetu Warszawskiego.

Blinava, Ė., \& Miatsel'skaia, E. (1980). Belaruskaia dyialektalohiia. Minsk: Vyshëĭshaia shkola.

Budz'ko, I. (2007). Linhvistychny i satsyialinhvistychny kharaktar belaruskaha pamezhzha: Da pastanoŭki prablemy. In E. Smułkowa \& A. Engelking (Eds.), Pogranicza Białorusi w perspektywie interdyscyplinarnej (pp. 259-280). Warszawa: Wydawnictwo DiG. 
Budźko, I. (2011). Gwary białoruskie rejonu brasławskiego: Geneza, geografia, uwarunkowania socjolingwistyczne. In E. Smułkowa (Ed.), Brasławszczyzna: Pamięć i współczesność (Vol. 1, Historia regionu. Charakterystyka socjolingwistyczna. Świadectwo mieszkańców, pp. 141-171). Warszawa: Wydawnictwa Uniwersytetu Warszawskiego.

Ėrker, A. (2015). Strukturnye cherty smeshannykh belorusskikh govorov na balto-slavianskom pogranich'e. Mainz: Kubon \& Sagner. (Slavolinguistica, 22).

Guszczewa, O. (2011). Zakres użycia języka rosyjskiego i jego oddziaływanie na gwary białoruskie i polszczyznę w rejonie brasławskim. In E. Smułkowa (Ed.), Brasławszczyzna: Pamięć i współczesność (Vol. 1, Historia regionu. Charakterystyka socjolingwistyczna. Świadectwo mieszkańców, pp. 214-246). Warszawa: Wydawnictwa Uniwersytetu Warszawskiego.

Hulitskaia, V. A., Hulitski, M. F., Zlobin, L. I., \& Rudakoŭskaia, Z. A. (1992). Belaruskaia i ruskaia dyialektalohiia. Minsk: Vyshëishaia shkola.

Jankowiak, M. (2007). Zakres funkcjonowania języka białoruskiego i stan zachowania gwary na przykładzie wybranych miejscowości w okolicach Horek w obwodzie mohylewskim. In E. Smułkowa \& A. Engelking (Eds.), Pogranicza Białorusi w perspektywie interdyscyplinarnej (pp. 293-315). Warszawa: Wydawnictwo DiG.

Jankowiak, M. (2009). Gwary białoruskie na Łotwie w rejonie krasławskim: Studium socjolingwistyczne. Warszawa: Slawistyczny Ośrodek Wydawniczy.

Kasatkin, L. L. (Ed.). (2005). Russkaia dialektologiia. Moskva: Izdatel'skiŭ tsentr "Akademiia".

Kryvitski, A. A. (2003). Dyialektalohiia belaruskaŭ movy. Minsk: Vydavetstva "Vyshëšshaia shkola".

Kryvitski, A. A. (2009). Belaruskaia natsyianal'naia movatvorchasts' i siarėdniaia (tsèntral'naia) dyialektnaia zona belaruskaŭ movy. In L. P. Kuntsèvich \& V. M. Kurtsova (Eds.), Khrèstamatyia pa belaruskă̌ dyialektalohii. Tsentral'naia zona (pp. 507-513). Minsk: Belaruskaia navuka.

Kuntsėvich, L. P., \& Kurtsova, V. M. (Eds.). (2009). Khréstamatyia pa belaruskă dyialektalohii: Tsentral'naia zona. Minsk: Belaruskaia navuka.

Kuraszkiewicz, W. (1963). Zarys dialektologii wschodniosłowiańskiej: Z wyborem tekstów gwarowych (2nd ed.). Warszawa: Państwowe Wydawnictwo Naukowe.

Kuryan, I. (2011). Charakterystyka idiolektów języka polskiego. In E. Smułkowa (Ed.), Brasławszczyzna: Pamięć i współczesność (Vol. 1, Historia regionu. Charakterystyka socjolingwistyczna. Świadectwo mieszkańców, pp. 184-206). Warszawa: Wydawnictwa Uniwersytetu Warszawskiego.

Leksichny atlas belaruskikh narodnykh havorak [LABNH]. (1993-1998). Minsk: Instytut Movaznaŭstva imia Iakuba Kolasa, Akadėmiia navuk Belarusi.

Pabis, I. (2011). Staroobrzędowcy - inni Rosjanie. In E. Smułkowa (Ed.), Brasławszczyzna: Pamięć i współczesność (Vol. 1, Historia regionu. Charakterystyka socjolingwistyczna. Świadectwo mieszkańców, pp. 207-213). Warszawa: Wydawnictwa Uniwersytetu Warszawskiego.

Pabis, I. (n.d.). Polskie wyspy gwarowe przełomu XIX i XX wieku na Białorusi (ze słownikiem). Unpublished manuscipt.

Rieger, J. (2014). Słownictwo polszczyzny gwarowej na Brasławszczyźnie. Warszawa: Uniwersytet Warszawski, Wydział „Artes Liberales”. 
Smułkowa, E. (Ed.). (2009). Brasławszczyzna: Pamięć i współczesność (Vol. 2, Słownictwo dwujęzycznych mieszkańców rejonu (Słownik brasławski)). Warszawa: Wydawnictwa Uniwersytetu Warszawskiego.

Smułkowa, E. (Ed.). (2011a). Brasławszczyzna: Pamięć i współczesność (Vol. 1, Historia regionu. Charakterystyka socjolingwistyczna. Świadectwo mieszkańców). Warszawa: Wydawnictwa Uniwersytetu Warszawskiego.

Smułkowa, E. (2011b). Sytuacja socjolingwistyczna i proces konwergencji języków na Brasławszczyźnie w świetle badań terenowych (1997-2007). In E. Smułkowa (Ed.), Brasławszczyzna: Pamięć $i$ współczesność (Vol. 1, Historia regionu. Charakterystyka socjolingwistyczna. Świadectwo mieszkańców, pp. 101-140). Warszawa: Wydawnictwa Uniwersytetu Warszawskiego.

Smułkowa, E., \& Engelking, A. (Eds.). (2007). Pogranicza Białorusi w perspektywie interdyscyplinarnej. Warszawa: Wydawnictwo DiG.

Thomason, S. (2001). Language contact: An introduction. Edinburgh: Edinburgh University Press.

Zakharova, K. F., \& Orlova, V. G. (1970). Dialektnoe chlenenie russkogo iazyka. Moskva: Izdatel'stvo "Prosveshchenie".

Zielińska, A. (2013). Mowa pogranicza: Studium o językach i tożsamościach w regionie lubuskim. Warszawa: Slawistyczny Ośrodek Wydawniczy.

\section{Dialectal zones of the Belarusian language as an example of language contacts between neighbouring nations}

\section{Summary}

The article regards dialectal zones of the Belarusian language, which, as opposed to the traditional division into dialectal belts and dialectal groups, were marked out mainly on the basis of lexical and not grammatical features. While the traditionally delineated dialects indicate ethnographic unity of the Belarusian nation, dialectal zones present cultural and historical contacts with neighbouring nations. We can distinguish five zones: north-western (contacts with the Baltic languages, mainly with Lithuanian, and the Polish language of the northern borderland), south-eastern (contacts with Russian and Ukrainian), western (contacts with Polish), eastern (contacts with Russian) and central. 


\section{Strefy dialektalne języka białoruskiego jako przykład językowych kontaktów $\mathrm{z}$ narodami sąsiednimi}

\section{Streszczenie}

Artykuł traktuje o strefach dialektalnych języka białoruskiego, które, w odróżnieniu od tradycyjnego podziału na pasy dialektów i grupy gwarowe, zostały wyznaczone przede wszystkim w oparciu o cechy leksykalne, a nie gramatyczne. O ile tradycyjne dialekty wskazują na etnogenetyczną wspólnotę narodu białoruskiego, o tyle strefy dialektalne na kulturowo-historyczne kontakty z narodami sąsiednimi. Wyróżnia się pięć stref: północno-zachodnią (kontakt $\mathrm{z}$ językami bałtyckimi, głównie litewskim, i polszczyzną północnokresową), południowo-wschodnią (z rosyjskim i ukraińskim), zachodnią (z językiem polskim), wschodnią (z językiem rosyjskim) oraz centralną.

Keywords: dialectal zones of the Belarusian language; Belarusian dialectology; language contact; linguistic borderland

Słowa kluczowe: strefy dialektalne języka białoruskiego; dialektologia białoruska; kontakty językowe; pogranicza językowe

\footnotetext{
Mirosław Jankowiak, Institute of Slavic Studies, Polish Academy of Sciences, Warsaw

Correspondence: mirek.jankowiak@gmail.com

The works was funded within the statutory activities of the Institute of Slavic Studies, Polish Academy of Sciences.

Competing interests: The author has declared he has no competing interests.
} 